\title{
PENINGKATAN EKO-EFISIENSI USAHA DENGAN PENERAPAN ENVIRONMENTAL MANAGEMENT ACCOUNTING (EMA)
}

\author{
Nuramal \\ Email: nuramal719@gmail.com \\ Prodi Akuntansi STIEM Bongaya \\ Jalan Letjen Pol.A.Mappaoudang No. 28 Makassar. \\ Muzdalifah \\ Email: muzdalifah@stiem-bongaya.ac.id \\ Prodi Akuntansi STIEM Bongaya \\ Jalan Letjen Pol.A.Mappaoudang No. 28 Makassar.
}

\begin{abstract}
ABSTRAK
Penelitian ini menggunakan eko-efisiensi usaha pada rumah sakit dengan menerapkan environmental management accounting sebagai bentuk tanggung jawab rumah sakit mengatasi limbah operasional. Adapun tujuan penelitian ingin mengetahui kegiatan-kegiatan eko-efisiensi usaha yang dilakukan oleh R.S Ibnu Sina YW-UMI Makassar dalam penerapan environmental management accounting dan mengetahui bentuk pelaporan akuntansi biaya lingkungan pada laporan yang di buat oleh R.S Ibnu Sina YW-UMI Makassar. Penelitian ini adalah jenis penelitian kualitatif dalam paradigma interpretif yang lebih memfokuskan pada interpretasi seseorang dalam sebuah simbol. Sumber data yakni hasil wawancara data primer dengan Kepala Bagian Instalasi Keselamatan\&Kecelakaan Kerja (K3) Rumah Sakit Ibnu Sina YW-UMI, data sekunder mengobservasi mengenai biaya-biaya lingkungan yang dikeluarkan. Hasil penelitian menemukan bahwa kegiatan eko-efisiensi pada rumah sakit Ibnu Sina YW UMI telah memperhatikan lingkungan sekitar dan masyarakatnya karena limbah klinis maupun non medis telah dikelola dengan baik. Environmental management accounting (EMA) telah memberikan informasi pengelolaan limbah pada eko-efisiensi material, air dan energi listrik. Bentuk laporan biaya lingkungan sudah diketahui dan namun belum dikelompokkan sesuai dengan kualitas biaya lingkungan yang ada.
\end{abstract}

Kata Kunci: eko-efisiensi, environmental management accounting

\section{ABSTRACT}

This study uses eco-efficiency of business in hospitals by implementing environmental management accounting as a form of hospital responsibility in dealing with operational waste. This research is a type of qualitative research in an interpretive paradigm which focuses more on the interpretation of a person in a symbol. The research objectives want to know the activities of eco-efficiency of business carried out in the application of environmental management accounting and to know the form of environmental cost accounting reporting on reports made by R.S Ibnu Sina YW-UMI Makassar. The data source is the results of primary data interviews with the Head of the Installation of Safety \& Work Accidents (K3) at the Ibnu Sina YW-UMI Hospital, secondary data observes the environmental costs incurred. The results of the study found that the eco-efficiency activities at the Ibnu Sina YW UMI hospital paid attention to the surrounding environment and society because clinical and non-medical waste had been well managed. Environmental management accounting (EMA) has provided waste management information on the eco-efficiency of materials, water and electrical energy. The form of environmental cost reports is known and but has not been grouped according to the quality of existing environmental costs.

Key Word : eco-efficiency, environmental management accounting (EMA) 


\section{PENDAHULUAN}

Saat ini, industri diharuskan melakukan pembauran metode produksinya dengan dengan penerapan pembangunan berkelanjutan sebagai acuan. Beberapa pendekatan pengelolaan yang ramah lingkungan agar limbah yang dihasilkan lebih sedikit salah satunya pendekatan Ekoefisiensi. Eko-efisien merupakan instrument tata kelola lingkungan yang menggunakan bahan baku, air dan energi sehingga memberi keuntungan ekonomi dan ekologi. (Sari \& dkk, 2012).

Eko-efisiensi perusahaan dapat dimajukan dengan inovasi sistem Environmental Management Accounting (EMA). EMA sebagai tata kelola lingkungan akan membawa dampak positif pada pengambilan keputusan dan keuangan perusahaan. Environmental Management Accounting (EMA) memberikan keterangan mengenai aliran persediaan dan dampaknya terhadap lingkungan berikut biaya lingkungan yang dikeluarkan sehingga dapat meningkatkan kinerja lingkungan pada perusahaan (Doorasamy \& Garbharran, 2015).

Rumah Sakit "IBNU SINA" UMI sebagai salah satu rumah sakit swasta di kota Makassar yang memberikan pelayanan kesehatan lengkap bagi masyarakat. Tentunya dalam aktivitas operasionalnya, memiliki berbagai macam limbah baik padat, cair, pasta (gel), maupun gas yang mengandung mikroorganisme phatogen bersifat infeksius, bahan kimia beracun dan sebagian bersifat radioaktif yang cenderung ada yang berdampak negatif pada lingkungan sekitarnya. Oleh karena itu, diperlukan penataan dan penyelesaian khusus atas limbah rumah sakit tersebut.

Prinsip Enviromental Management Accounting (EMA) dalam akuntansi dapat membantu perusahaan dalam mengidentifikasi biaya-biaya lingkungan. EMA juga dapat berfungsi dalam perlindungan lingkungan melalui pengungkapan sukarela dalam laporan keuangan. Aspek EMA yakni Physic Environmental Management Accounting (PEMA) merupakan jumlah penggunaan energi input dan output pada suatu perusahaan dalam bentuk physic dan Moneter Environmental Management Accounting (MEMA) merupakan informasi keuangan untuk manajemen internal. (IFAC, 2005).

EMA berperan menunjang pengambilan keputusan stakeholder dalam berinvestasi (Kurniati, Sultan Haji, \& Renaningtyas, 2018) karena penggunaan EMA membentuk kebiasaan yang dapat mengurangi polusi dan meminimalisasi limbah dalam suatu industri. (Purnomo, 
2014) sehingga perusahaan dapat melakukan penghematan biaya dan berdampak pada peningkatan kinerjanya.

Penelitian terkait akuntansi manajemen lingkungan di Indonesia diantaranya telah dilakukan oleh (Azizah, Dzulkiron, \& Endang, 2013) menemukan bahwa eko-efisiensi perusahaan sebagai wujud dari akuntansi manajemen lingkungan. Lebih lajut, (Nisa, Sutan Haji, Suharto, \& Sukrisno, 2015) mengemukakan bahwa eko-efisiensi dimaksudkan untuk meningkatkan kualitas hidup melalui pembuatan produk yang harganya dapat bersaing dan tidak membawa dampak pada lingkungan.

Hasil temuan (Chikmatin) mempertegas bahwa penerapan EMA termasuk dalam system eco-efisiensi yang dapat meningkatkan laba perusahaan. (Kania, Nurleli, \& Lestari, 2017) yang meneliti pengaruh penerapan akuntansi manajemen lingkungan terhadap kinerja lingkungan pada perusahaan tekstil di Kabupaten Bandung telah menemukan bahwa dengan menerapkan akuntansi manajemen lingkungan maka kinerja lingkungan perusahaan masuk dapat meningkat.

Penelitian ini menggunakan eko-efisiensi usaha pada rumah sakit dengan menerapkan environmental management accounting sebagai bentuk tanggung jawab rumah sakit mengatasi limbah operasional. Adapun tujuan penelitian ingin mengetahui kegiatankegiatan eko-efisiensi usaha yang dilakukan oleh R.S Ibnu Sina YW-UMI Makassar dalam penerapan environmental management accounting dan mengetahui bentuk pelaporan akuntansi biaya lingkungan pada laporan yang di buat oleh R.S Ibnu Sina YW-UMI Makassar.

\section{Teori Legitimasi (Legitimacy Theory)}

Teori legitimasi dalam penelitian ini menjelaskan keterkaitan masalah lingkungan dengan cara perusahaan mengungkapkan tanggungjawab sosial yang dilakukannya pada lingkungan sekitar. Legitimasi menjadi acuan norma yang penting dalam mengontrol aktivitas perusahaan dan dengan legitimasi perusahaan dapat mengawasi dampak kegiatan perusahaan pada lingkungan sekitar sehingga perusahaan mampu menunjukkan kinerjanya baik dan dapat dilihat apakah masyarakat sekitarnya bias menerima perusahaan tersebut. 


\section{METODE PENELITIAN}

Penelitian ini adalah jenis penelitian kualitatif dalam paradigma interpretif yang lebih memfokuskan pada interpretasi seseorang dalam sebuah simbol. Sumber data yakni hasil wawancara data primer dengan Kepala Bagian Instalasi Keselamatan\&Kecelakaan Kerja (K3) Rumah Sakit Ibnu Sina YW-UMI, data sekunder mengobservasi mengenai biaya-biaya lingkungan yang dikeluarkan. Variabel yang diamati dalam penelitian ini yaitu kegiatan ekoefisiensi yang dilakukan oleh Rumah Sakit Ibnu Sina YW-UMI yang terdiri dari (Hansen\&Mowen, 2009) : biaya pencegahan, biaya deteksi lingkungan, biaya kegagalan internal dan biaya kegagalan eksternal yang dianalisis terhadap perlakuan akuntansi lingkungan.

\section{HASIL DAN PEMBAHASAN}

\section{Hasil}

\section{Kegiatan eko-efisiensi dalam penerapan environmental management accounting di Rumah Sakit Ibnu Sina YW-UMI}

Kegiatan eko-efisiensi dalam penerapan EMA di Rumah Sakit Ibnu Sina YW-UMI berdasarkan hasil wawancara dengan dr. R.P.I.A, MARS selaku Kepala Bagian Instalasi K3 diuraikan sebagai berikut :

1) Kegiatan Pengelolaan Limbah Padat Klinis

Limbah padat medis seperti limbah infeksius dari ruang poliklinik dan perawatan, limbah farmasi dari apotik, limbah patologi dari labolatorium, limbah kimiawi dari ruang otopsi dan semua limbah medis butuh penanganan khusus, untuk itu disediakan troli tertutup dari bahan yang yang kuat, anti air dan anti karat dan dikirim ke tempat inceneator atau dibakar yang di awasi oleh perusahaan mitra PT M dan dipantau rutin setiap bulan oleh instalasi K3.

2) Kegiatan Pengelolaan Sampah Domestik

Limbah domestik berasal dari sampah non medis dari ruang administrasi perkantoran, ruang tunggu poliklinik, ruang inap, divisi gizi/dapur, halaman rumah sakit, parkiran, taman, dan beberapa unit yang memiliki sampah. Disediakan Tempat Pembuangan Sampah non medis di tiap sudut ruangan agar memudahkan orang membuang sampahnya. Sampah non medis 
ini diangkut oleh perusahaan mitra PT M paling lambat dalam 24 jam agar tidak menumpuk dan setiap minggu instalasi K3 memantau secara rutin sampah non medis tersebut.

3) Kegiatan pengelolaan Limbah Cair

Pengelolaan limbah cair dilakukan agak lebih rumit dibandingkan limbah padat, maka beberapa tahapan dalam mengelola limbah yakni limbah disaring sebelum di proses dengan mesin IPAL oleh balai K3. Limbah cair diproses dengan preatmen yang berfungsi menambahkan kandungan air dalam limbah agar pada saat masuk ke mesin IPAL kandungan air bersihnya lebih banyak, kemudian diolah pada tahap Reaktor Biofilter berfungsi untuk membantu bakteri-bakteri yang memakan zat-zat berbahaya yang beradadalam limbah. Dengan adanya perkembangbiakan pada proses unaerobic Biofilter akan bermanfaat ketika di Reaktor Biofilter. Semakin banyak bakteri-bakteri yang berkembang biak tentunya semakin bagus bagi pengelolaan dalam sebuah mesin Instalasi Pengolahan Air Limbal (IPAL), selanjutnya limbah disaring kembali dalam tahap filter pump karena kemungkinan masih ada limbah padat seperti gumpalan dalam limbah. Post Treatmen ini berguna untuk menghilangkan parasit yang pertama yaitu dengan cara memberi kaporit. Dimana kaporit ini sebagai penghasil oksidasi yang akan menyelamatkan dari kandungan yang bersifat pengotor dalam air seperti besi, mangan kadar bersih tinggi dan bakteri Sinar UV yang berfungsi sebagai kaporit untuk mematikan bakteri-bakteri yang ada namun bedanya dengan kaporit, sinar UV lebih detail dimana tidak ada bakteri yang dapat lolos. Colnation ini sebagai alat untuk pembersihan ulang menghilangkan faktor-faktor yang dapat membahayakan lingkungan hidup seperti zat berbahaya seperti bakteri, kuman atau virus dengan bentuk seperti sumur.

4) Efisiensi Pemakaian Air Bersih

Air bersih yang dibutuhkan cukup banyak sebanding dengan rasio jumlah pasien, utamanya saat ini di rawat inap pada penyakit dalam yang meningkat, ketersediaan air bersih harus terjaga. Kegiatan inspeksi sanitasi dilaksanakan oleh instalasi K3 untuk mengawasi kualitas air, setiap titik air bersih dari setiap unit bangunan di rumah sakit Ibnu Sina YW UMI dipastikan bisa mencukupi kebutuhan air.

5) Kegiatan Pengelolaan energi listrik

Efisiensi penggunaan energi listrik dilakukan agar tidak terjadi pemborosan dsn meminimalisasi pengeluaran biaya. Manajemen rumah sakit Ibnu Sina merekomendasi 
model penerapan managemen energy untuk meningkatkan eko-efisiensi. Listrik yang dipakai di setiap ruangan wajib dimatikan bila tidak dipakai lagi, seperti pada rawat jalan setelah poliklinik beroperasi listrik wajib dimatikan pada malam hari, di unit rawat nginap juga diawasi penggunaan listrik untuk ruangan yang kosong.

Uraian di atas nampak bahwa kegiatan eko-efisiensi pada rumah sakit Ibnu Sina YW UMI telah memperhatikan lingkungan sekitar dan masyarakatnya karena limbah medis maupun non medis telah dikelola dengan baik Eko-efisien telah berfungsi dalam proses perubahan lingkungan dan sumber daya alam. Metode EMA dalam eko-efisien akan memberikan informasi pengelolaan limbah di rumah sakit Ibnu Sina YW UMI telah terjadi efisiensi pada material, air dan energi listrik.

\section{Bentuk Laporan Biaya Lingkungan di Rumah Sakit Ibnu Sina YW-UMI}

Rumah Sakit Ibnu Sina YW-UMI selama tahun 2018 telah mengeluarkan biaya lingkungan berikut:

Tabel 1

Laporan Biaya Lingkungan RS Ibnu Sina YW-UMI

Periode Desember 2018

\begin{tabular}{clrr}
\hline No. & \multicolumn{1}{c}{ Kegiatan } & \multicolumn{1}{c}{ Biaya } \\
\hline 1. & Kalibrasi alat medis & $\mathrm{Rp}$ & 45.000 .000 \\
2. & Perbaikan dan pemeliharaan IPAL & $\mathrm{Rp}$ & 9.000 .000 \\
& & & \\
3. & Pemantauan lingkungan & $\mathrm{Rp}$ & 12.000 .000 \\
4. & Penanganan dan pemusnahan sampah medis/non medis & $\mathrm{Rp}$ & 180.000 .000 \\
5. & Pelatihan penanggulangan dan simulasi kebakaran & $\mathrm{Rp}$ & 28.000 .000 \\
6. & Pengisian Alat Pemadan Api Ringan (APAR) & $\mathrm{Rp}$ & 8.000 .000 \\
7. & Pengadaan dan pemasangan rambu kedaruratan & $\mathrm{Rp}$ & 5.000 .000 \\
8. & Pelatihan keselamatan kerja (K3) & $\mathrm{Rp}$ & 10.000 .000 \\
\hline \multicolumn{1}{c}{ Total } & $\mathrm{Rp}$ & 297.000 .000
\end{tabular}

Sumber: Internal RS. Ibnu Sina YW-UMI, data diolah (2020)

Tabel di atas menjelaskan bahwa data biaya yang dikeluarkan berkaitan dengan biaya lingkungan sudah diketahui namun belum dikelompokkkan sesuai dengan kualitas biaya lingkungan yang ada. Untuk pengakuan biaya lingkungan diakui saat biaya telah memberi manfaat walaupun transaksi belum dilakukan pembayaran secara tunai. Environmental management accounting (EMA) untuk biaya lingkungan telah disajikan disajikan dan diungkapkan dalam Catatan Atas Laporan Keuangan Rumah Sakit Ibnu Sina YW UMI dan sudah menjelaskan komponen-komponen biaya lingkungan Nampak di Laporan Laba rugi masuk 
dalam perhitungan biaya administrasi umum. Oleh karena itu, penelitian ini merujuk teori (Hansen\&Mowen, 2009) yang membagi-bagi biaya sesuai kategori kualitas lingkungan yakni biaya pencegahan, biaya deteksi lingkungan, biaya kegagalan internal lingkungan dan biaya kegagalan eksternal lingkungan (environmental eksternal failure costs) nampak pada tabel :

Tabel 2

Laporan Biaya Lingkungan (teori)

Periode Desember 2018

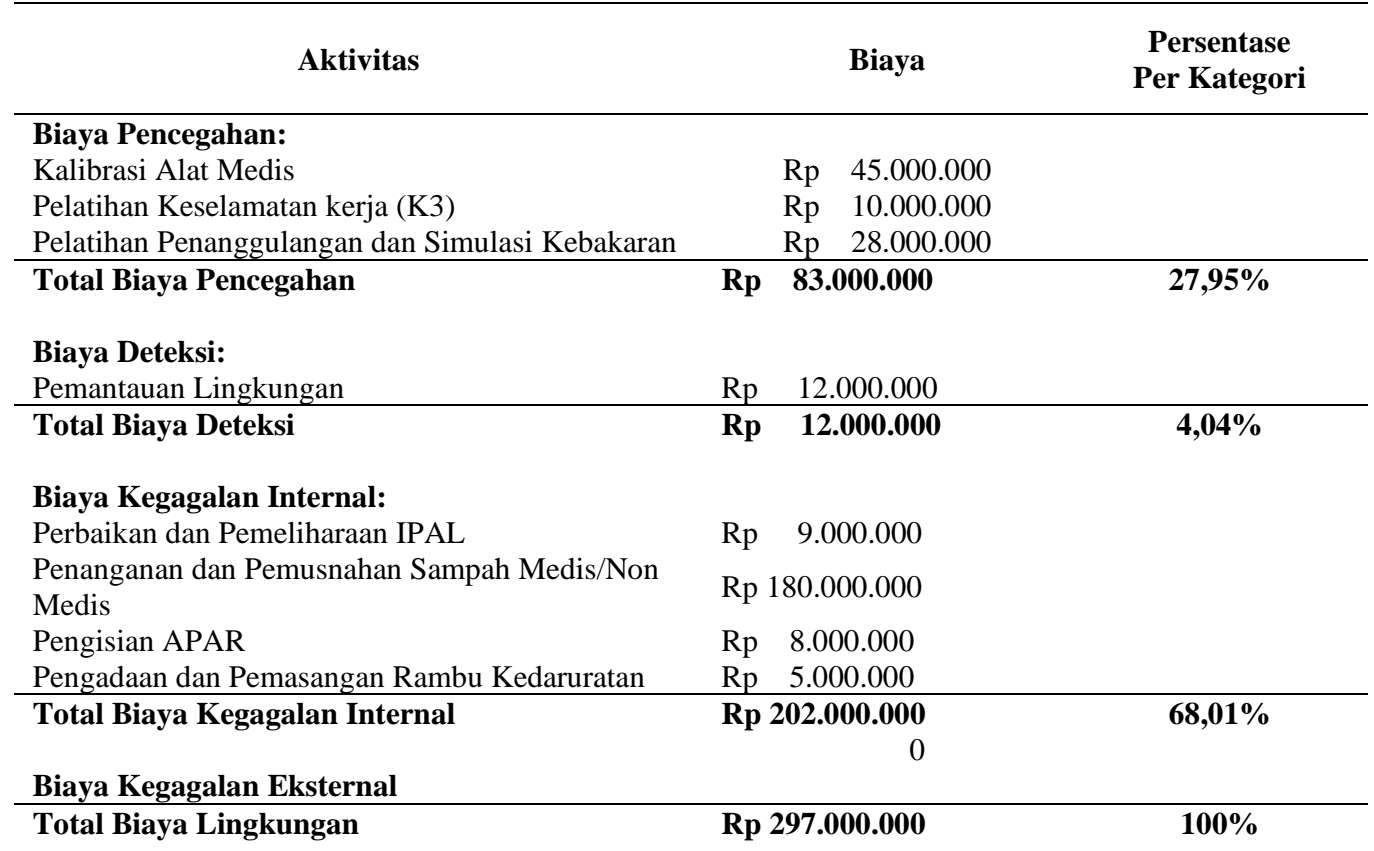

Sumber: Data Diolah Peneliti (2020)

Setelah mengkategorikan biaya kualitas lingkungan maka dapat dilihat :

1. Biaya pencegahan dilakukan untuk mencegah limbah yang memberi dampak negatif pada lingkungan. penelitian ini menemukan bahwa dalam biaya pencehahan, Rumah Sakit Ibnu Sina YW-UMI telah mengelurakan biaya lingkungan untuk pencegahan tercermarnya lingkungan sekitar yang di sebabkan oleh limbah. Namun, belum ada pengidentifikasian biaya pencegahan berdasarkan kualitas biaya lingkungan secara khusus. Seharusnya, dibuat kategori biaya pencegahan terdiri dari kalibrasi alat medis untuk menjamin kualitas alat yang akan digunakan, kemudian pelatihan k3 dan pelatihan penanggulangan dan simulasi kebakaran untuk memberi bekal kepada pegawai/perawat agar bisa memberi pemahaman kepada pasien supaya tidak terkena bahaya dari limbah pembuangan sampah dengan total biaya pencegahan lingkungan yang dikeluarkan selama tahun 2018 sebesar 27,95\%. 
2. Biaya deteksi lingkungan merupakan biaya-biaya untuk penentuan produk, proses dan kegiatan yang dilakukan rumah sakit apakah sudah sesuai dengan standar lingkungan yang berlaku atau tidak. Biaya pemantauan lingkungan yang dilakukan oleh rumah sakit Ibnu Sina YW-UMI yaitu rutin melaksanakan uji pencemaran pada air bersih dan memastikan tidak ada bakteri pada makanan yang akan diberikan kepada pasien.Total biaya deteksi lingkungan yang dilakukan pada tahun 2018 sebesar 4,04\%.

3. Biaya kegagalan internal yakni biaya kegiatan pengelolaan yang dilakukan dari limbah dan sampah yang tidak dibuang di lingkungan sekitarnya. Adapun biaya kegagalan internal yang dikeluarkan berasal dari biaya perbaikan dan pemeliharaan IPAL, penanganan dan pemusnahan sampah medis dan non medis, pengisian APAR serta pengadaan dan pemasangan rambu kedaruratan. Biaya kegagalan internal yang dikeluarkan sebesar 68,01\%.

4. Biaya kegagalan eksternal adalah biaya untuk kegiatan yang dilakukan setelah melepas limbah atau sampah di lingkungan sekitarnya. Di Rumah sakit Ibnu Sina YW UMI tidak ditemukan biaya kegagalan eksternal karena menurut hasil wawancara belum pernah ada masyarakat sekitar yang protes ada bau tak sedap dari insenerator.

Hasil penelitian (Nisa, Sutan Haji, Suharto, \& Sukrisno, 2015) mendukung hasil penelitian ini bahwa eko-efisiensi dimaksudkan untuk meningkatkan kualitas hidup melalui pembuatan produk yang harganya dapat bersaing dan tidak membawa dampak pada lingkungan. Hasil penelitian ini mendukung pula hasil penelitian (Irawan, Dzulkorim, \& Zahroh, 2016) yang menyatakan pengelolaan limbah yang memenuhi standard baku mutu limbah yang telah diatur oleh peraturan pemerintah adalah tujuan dari penerapan biaya lingkungan.

Hasil penelitian ini tidak mendukung teori (Hansen\&Mowen, 2009) mengklasifikasikan biaya lingkungan menjadi yang biaya pencegahan, biaya deteksi lingkungan, biaya kegagalan internal dan biaya kegagalan eksternal.

\section{KESIMPULAN}

Kesimpulan penelitian ini yaitu:

1. Kegiatan eko-efisiensi pada rumah sakit Ibnu Sina YW UMI telah memperhatikan lingkungan sekitar dan masyarakatnya karena limbah medis maupun non medis telah dikelola dengan baik. Environmental management accounting (EMA) telah memberikan informasi pengelolaan limbah pada eko-efisiensi material, air dan energi listrik. 


\section{Jurnal Ekonomi Pembangunan Vol. 6, No.2 (2020) 102-111}

2. Bentuk laporan biaya lingkungan sudah diketahui dan namun belum dikelompokkkan sesuai dengan kualitas biaya lingkungan yang ada. Biaya lingkungan dicatat pada biaya administrasi umum dan disajikan dalam Catatan Atas Laporan keuangan.

Penelitian ini menyarankan kepada Rumah Sakit Ibnu Sina YW-UMI untuk membuat laporan biaya lingkungan yang sudah mengelompokkan biaya berdsarkan kualitasnya agar manajemen mengetahui berapa besar biaya yang dikeluarkan untuk pengelolaan limbah sehingga mudah untuk pengambilan keputusan.

\section{DAFTAR PUSTAKA}

Azizah, N., Dzulkiron, M. A., \& Endang, M. G. (2013, Desember). Environmental Management Accounting (EMA) Sebagai Bentuk Eco-Efficiency Dalam Meningkatkan Keunggulan Kompetitif Perusahaan (Studi Pada PT Perkebunan Nusantara (Unit Usaha Pabrik Gula Ngadiredjo Kabupaten Kediri Periode Tahun 2009-2011). Jurnal Adminstrasi Bisnis $(J A B), 6(2)$.

Chikmatin, E. (n.d.). Analisis Implementasi EMA sebagai bentuk Eco-Eficiency Pada CV Mikado. Seminar Nasional Ekonomi dan Bisnis Dewantara, (pp. 1-12). 2019.

Doorasamy, M., \& Garbharran, H. (2015). Assessing The Use Of Environmental Management Accounting As A Tool To Calculate Environmental Costs and Their Impact On A Company'S Environmental Performance Internasional. Journal Of Management Research and Business Strategy, 4(1), 35-52.

Hansen\&Mowen. (2009). Akuntansi Manajerial (8 ed., Vol. 1). Jakarta: Salemba Empat.

IFAC, I. F. (2005). International Guidance Document, Environmental Management Accounting. New York: IFAC.

Indrawati, N., \& Rini, I. S. (2018). Analisis Penerapan Akuntansi Lingkungan pada Badan Rumah Sakit Umum Daerah (BRSUD) Tabanan. Jurnal Krisna : Kumpulan Riset Akuntansi, 9(2), 85-95.

Irawan, A., Dzulkorim, M. A., \& Zahroh. (2016). Efektivitas Biaya Lingkungan Dalam Upaya Meminimalkan Pencemaran Lingkungan (Studi pada PG Gempolkrep Mojokerto Periode 2013-2015). Jurnal Adminstrasi Bisnis, 40(1).

Jaya, H. (2015). Analisis Penerapan Akuntansi Biaya Lingkungan terhadap Laba Perusahaan PT. IMECO BATAM TUBULAR. Jurnal Measurement, 9(1).

Kania, D., Nurleli, \& Lestari, R. (2017). Pengaruh Penerapan Akuntansi Manajemen Lingkungan Terhadap Kinerja Lingkungan (Survey Pada Perusahaan Tekstil Yang Telah Mengikuti PROPER di Kabupaten Bandung Tahun 2015-2016. Kajian Akuntansi, 18(1), 13-21.

Kurniati, E., Sultan Haji, A. T., \& Renaningtyas, A. P. (2018). Environmental Management Accounting (EMA) Pada Unit Urea PT. Petrokimia Gresik. Jurnal Sumber Daya Alam dan Lingkungan, 5(3). 
Nisa, F., Sutan Haji, A., Suharto, B., \& Sukrisno. (2015). Penentuan Tingkat Eko-efisiensi Proses Produksi Biji Kakao Menggunakan Life Cycle Assessment Pada Unit Produksi di Pusat Penelitian Kopi dan Kakao Indonesia. Jurnal Sumber Daya Alam dan Lingkungan, 2(2), 23-29.

Purnomo, O. A. (2014). Penerapan Environmental Management Accounting dalam Upaya Meningkatkan Kinerja PT Z di Sidoarjo. Jurnal ilmiah Universitas Surabaya, 1-16.

Ridwan, M., Prita D, S., \& Sudarno, S. (2019). Klasifikasi Biaya Lingkungan pada Rumah Sakit Jember. e-Jurnal Ekonomi, Bisnis\& Akuntansi, VII(1), 102-107.

Sari, D. P., \& dkk. (2012). Pengukuran tingkat eko-efisiensi Menggunakan Lifecycle Assesment untuk Menciptakan Suistantinable Production di Industri Kecil Menengah Batik. Jurnal Teknik Industri, 14(2), 137-144.

Sela, A., Karamoy, H., \& Mawikere, L. M. (2019). Analisis Penerapan Akuntansi Lingkungan Pada RSUD Dr Sam Ratlangi Tondano. Indonesia Accounting Journal, 1(2), 63-73. 